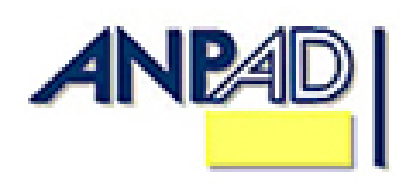

Available online at http://www.anpad.org.br/bar

BAR, Rio de Janeiro, v. 9, n. 4, art. 5, pp. 454-474, Oct./Dec. 2012

(cc) EY-NO

\title{
Hope, Perceived Financial Risk and Propensity for Indebtedness
}

Lucia Barros *

E-mail address: lubarros@gvmail.br Fundação Getúlio Vargas - EAESP/FGV São Paulo, SP, Brazil.

Delane Botelho E-mail address: delane.botelho@fgv.br Fundação Getúlio Vargas - EAESP/FGV São Paulo, SP, Brazil. 


\begin{abstract}
Hope is an important construct in marketing, since it is an antecedent of important marketing variables, such as trust, expectation and satisfaction (MacInnis \& Mello, 2005). Specifically, literature suggests that hope plays an important influence in risk perception (MacInnis \& Mello, 2005) and propensity for indebtedness (Fleming, 2008). Thus, we aim to investigate the relationships among hope, risk perception related to purchasing and consumption and propensity for indebtedness by conducting two empirical studies. The first is a laboratory experiment, which accessed hope and risk perception of getting a mortgage loan. The second is a survey, investigating university students' propensity to get indebted to pay for their university tuition, analyzed through the Structural Equations Modeling method. These studies found that higher levels of hope predicted an increase in the propensity to accept the mortgage loan, independent of actual risks, and an increase in the propensity of college students to get indebted to pay for their studies. In addition, the first study suggests that hope may lead to a decrease in risk perception, which, however, wasn't confirmed by the second study. Finally, this research offers some methodological contributions, using an experimental approach to understand hope and its relationship with perceived financial risk and propensity for indebtedness.
\end{abstract}

Key words: hope; risk perception; propensity for indebtedness; consumer behavior. 


\section{Introduction}

In general, people hope everyday: when a man applies for a new job, he hopes to get it; when a mother sends her children to school, she hopes they will have a good future; when a person buys a lottery ticket, s/he hopes to win. Hope seems to be pervasive and because it can be found in everyone's mind, it has become an important construct in a number of fields, such as Philosophy (Bloch, 1986), Theology (Moltmann, 1967), Psychology (Snyder, 2000), Nursery (Cutcliffe \& Herth, 2002) and Medicine (Schneiderman, 2005). Recently, hope was also found to be an important construct in marketing, being an antecedent of a number of important marketing variables, such as trust, expectation and satisfaction (MacInnis \& Mello, 2005). However, little research in the marketing literature has investigated hope (MacInnis \& Chun, 2007; MacInnis \& Mello, 2005; Vanzellotti, 2007).

One hopes when s/he has a goal and strongly believes it can be achieved. Goals are often related to acquisition or consumption, either directly (e.g. to buy a house) or indirectly (e.g. to buy an airplane ticket in order to enjoy a wonderful vacation), so hope has become increasingly important in the consumer behavior field. Specifically, it has been suggested that hope plays an important role in personal credit acquisition due to the fact that hope renders it possible for the individual to dream about enjoying a different future despite current deficiencies. However, this relationship between hope and propensity for indebtedness has only been investigated by Fleming's (2008) qualitative research.

Also, literature suggests that high hope can lead to lower perceived risk, which can lead consumers to harmful behaviors (Fleming, 2008). For instance, a consumer who has a high level of hope can underestimate risks and be more prone to indebtedness. Perceived risk in purchase decisions may be lower when hope is strong, since stronger levels of hope: (a) increase the perception that the desired goal will happen; (b) lower the perception of the likelihood of negative consequences and of their severities (MacInnis \& Chun, 2007). Although these authors have not empirically tested these propositions, those reasons make it reasonable to suppose that it is by lowering perceived risk that hope influences the propensity for indebtedness.

However, the nature of the relationship of these two variables is still unclear. For example, instead of reducing perceived risk, hope may just increase the perception that the risk-return relationship is worthwhile (Chen, 2007). Some studies found that higher levels of hope are related to preventive behaviors (Snyder, 2000), which would lead to an understanding that hope would actually increase perceived risk, and other studies found that a decrease in perceived risk would not necessarily lead to riskier behaviors (Temoshok, Sweet, \& Zich, 1987).

This article ${ }^{(1)}$ empirically investigates the influence of hope on perceived risk (specifically financial perceived risk) and on propensity for indebtedness. Our findings may contribute to the existing literature by: (a) providing empirical evidence to a causal relationship among hope, financial perceived risk and propensity for indebtedness, which has already been pointed only by theoretical and qualitative research; (b) demonstrating whether it is possible to integrate two relationships already found in the literature (hope and perceived risk, and hope and propensity for indebtedness) in a single model. The article is structured as follows: first we review the literature about hope and its related concepts, perceived risk and propensity for indebtedness, and then we explain the two empirical studies, demonstrating their method and results. We conclude by discussing the finding's implications to the literature, to the marketing practice and public policy, and also suggest avenues for future research. 


\section{Theory}

\section{What hope is}

Some scholars conceptualize hope as an emotion (MacInnis \& Mello, 2005; Nenkov, MacInnis, \& Morrin, 2009) evoked in response to an uncertain but possible goal-congruent outcome. They understand that hope is a feeling of wanting something, but being unsure about the possibility of getting it. Others consider hope a cognitive set (Snyder 2000) that is based on a reciprocally-derived sense of successful agency and pathways. Agency is the motivational component to propel people along their imagined routes to goals, while pathways are these imagined routes needed to achieve the desired goal. Together, they enhance each other, since they are continuously affecting and being affected by each other as the goal pursuit process unfolds (Snyder, 2000). Nevertheless, according to Day (1991) hope has both emotional and cognitive components, since it involves a combination of belief, which has cognitive purport, and desire, which does not.

Hope arises from the belief or expectancy that a future outcome can possibly be achieved, since it is positive and goal congruent, important and uncertain. Those characteristics of hope are detailed as follows: (a) future orientation: hope is always future oriented, meaning that it is based on outcomes that have not happened yet, (b) congruency to positive goals: neither negative outcomes nor outcomes contrary to our wishes will produce hope. In a benign environment, goal congruency means that a favorable outcome could occur, while in an aversive or threatening environment a negative outcome could be avoided or solved (e.g. one might hope for getting a salary raise - favorable outcome in a benign environment - or that s/he will not have cancer - avoiding a negative outcome in a threatening environment); (c) importance: there is no hope for ordinary subjects and the level of hope can vary according to the will, so people will not feel hope when they do not want to reach their goal anymore (Averill, Catlin, \& Chon, 1990); (d) perceived possibility: hope arises with an evaluation of possibility, so a person can hope even when the likelihood of a certain result is very low; (e) expectancy: when one perceives a situation as possible, s/he starts to believe or to expect a certain result (those two characteristics, perceived possibility and expectancy, can be exemplified by a person expecting to be fired from her/his job because there is a high probability due to a situational crisis, but still having hope of not being fired due to the possibility of maintaining her/his job); (f) uncertainty: hope appears when one perceives barriers to the desired goals. Goals with $100 \%$ of probability of attainment (i.e. it is certainly going to happen) do not require hope, while goals with $0 \%$ of probability (i.e. it is certainly not going to happen) do not produce hope (Averill et al., 1990).

Because of all these characteristics, hope seems to be more than just the absence of hopelessness (i.e. one may not hope that $\mathrm{s} / \mathrm{he}$ will find a new job not because $\mathrm{s} / \mathrm{he}$ feel hopeless about it, but because it is just not important). Also, hope can have either a promotion or prevention focus, which means that one can hope that a favorable outcome will be achieved (e.g. win the lottery) or that an undesired outcome will be avoided (e.g. not have cancer) (Poels \& Dewitte, 2008).

\section{What hope is not}

When thinking about hope, a lot of words come to mind, such as expectations, optimism, confidence, faith and desire. So, we provide understanding of those constructs which are often related to hope, trying to differentiate them.

Expectations: unlike hope, expectation is a construct already extensively explored in the marketing literature (Fleming, 2008). Expectations are the perception of likelihood that reflects the perceived probability that an outcome will be achieved (MacInnis \& Chun, 2007). There is hope only when the outcome is goal congruent; while there are expectations for goal congruent, incongruent and irrelevant outcomes (e.g. a person can have expectations about losing his/her job, but still hope to keep it). There is only hope for important outcomes; while there can be expectations for ordinary ones. Also, it seems that talking about hope involves more passion: Vanzellotti (2007) found in her 
interviews that the word expectations was used for more realistic and less passionate examples than the word hope. Finally, for hope to exist, the outcome must have a higher degree of uncertainty than for expectations.

Optimism: optimism is a personality trait that makes one assume that negative outcomes are momentous and their causes are external (Seligman, 1991), so a person who is optimistic has generalized joy-producing outcomes expectancies and copes well with life challenges (Carver, Scheier, \& Weintraub, 1989). While optimism produces generalized expectations, for hope to exist there must be a specific goal (Bruininks \& Malle, 2005), which means that if one is optimistic, s/he will believe that everything is going to be all right, while one hopes that specific outcomes such as getting a new job or losing weight will happen. Hope is something experienced by everyone, in different parts of their lives, while only some people are optimistic. Also, while hope can be caused by outcome congruent information, optimism is not caused by specific events (Bruininks \& Malle, 2005). Optimism is sometimes referred to as a personality trait, thus it would exist independently from a particular situation.

Confidence: confidence can be conceptualized as the perceived certainty about someone's future behavior (Das \& Teng, 1998). While both hope and confidence arise from future uncertain situations, the uncertainty aspect seems stronger for hope (MacInnis \& Chun, 2007). When one is confident that something will happen, s/he does not think about the likelihood of it not happening. If this person hopes for something, in contrast, s/he wants it to happen, but is aware of the possibility of an undesired outcome.

Faith: both hope and faith are part of the values from many religions (Smith, 2005). But, unlike faith, hope can be found in non-religious contexts (e.g. a Christian may hope to go to heaven after death - religious context - but one can also hope to win the lottery - non-religious context). Specifically, hope in purchases and consumption seems to be seldom related to religion, but to the achievement of desired outcomes from a number of different natures. While hope is always future oriented, faith can be future, present or past oriented (e.g. a Christian can have faith that Jesus existed, that God is protecting her/him or that s/he will go to heaven after death). While someone must want an outcome to happen when s/he has hope, the same does not happen with faith (Vanzellotti, 2007), since faith does not require an outcome (e.g. a Christian may have faith in God and not want, wish, desire, yearn, expect or hope for any outcome to happen). Also, hope is influenced by the environment while faith seems to depend on individual values (MacInnis \& Chun, 2007).

Desire: for hope to exist, the outcome must be important, i.e. it has to be desired beforehand. Because hope and desire are always related (Belk, Ger, \& Askegaard, 2003), it is not always easy to recognize whether a certain behavior is guided by desire alone or whether hope is also there. However, they are basically different in four ways:

1. Possibility level: even though one only hopes for uncertain outcomes, $s /$ he must perceive them as possible (Lazarus, 1999), but a desire can be a mere fantasy, so one can desire something which is perceived to be impossible. For instance, one can desire to fly or to live forever, without hoping that any of these outcomes will happen;

2. Desire needs not to come true, it can be reached through dreams (Belk et al., 2003), so it is reasonable that hope is more action-driven than desire alone (Snyder, 2000);

3. While hope is future oriented, desire can be also past and present oriented (e.g. one can desire to have chosen medical school instead of business school in the past, or may have a desire of eating a chocolate cake in the present time);

4. Hope needs a minimum degree of uncertainty to exist, which is not the case for desires (e.g. if one has a chocolate cake in the fridge, s/he can desire to eat a piece of it, but s/he will not hope to do so, because $s /$ he is certain $s /$ he can do it). 


\section{Hope and perceived risk}

Risk can be conceptualized as the probability of events and the magnitude of their specific consequences (Taylor, 1974). Thus, a very risky situation should involve both high probability and severe consequences, and a situation which is very likely to happen, but does not produce severe consequences, may be perceived as equally risky as another situation, which is not very likely to happen, but produces severe consequences.

There are mechanisms to change the way risk information is processed and, as a consequence, perceived. The concept of perceived risk was first explained by Bauer (1960) as a psychological and subjective construct that reflects the extent to which a product or service is perceived to have uncertain, personal, and negative consequences. Perceived risk is associated with the anticipation of negative outcomes (Johnson, Sivadas, \& Garbarino, 2008), and it is composed by two components: inherent risk (the latent risk a product holds) and handled risk (the amount of conflict the product is able to arise when the consumer chooses a brand). Inherent risk increases when the consumer feels that quality varies widely in a product class and that the mean level of quality in the product class is low. Handled risk, in contrast, arises when a consumer chooses a brand from a specific product class, and decreases with knowledge of or information about the product class. Handled risk includes the effects of particular information, such as brand information, whereas inherent risk deals with the riskiness a consumer feels if no information is assumed. For example, a consumer may feel there is a great deal of risk associated with the product class aspirin. However, s/he has a favorite brand which s/he buys with confidence. In this case, inherent risk is high, but handled risk may be low for aspirin. This implies that in a case where a consumer has no information, handled and inherent risk should be the same (Bettman, 1973). In other words, inherent risk is related to the product class itself, handled risk to the specific product purchase situation (Kim \& Lee, 2012).

Risk is a construct of a multidimensional nature (Jacoby \& Kaplan, 1972), involving, among others, economic, social, psychological, or physical domains and the perceived risk in one domain can change the perceived risk in the other (Almeida \& Botelho, 2008). For instance, the authors explain that non-financial risks can make financial risks to be perceived as higher.

Even these domains can be divided into sub-domains, depending on the situation. For instance, the economic or financial domain is often seen in a different way due to the situation's perceived controllability. For example, gambling is seen as riskier than investing, even though both have financial consequences (March \& Shapira, 1987; Weber, Blais, \& Betz, 2002). In a purchasing context, buying a product is risky when there is the possibility of financial, performance, or psychological losses (Horton, 1976).

According to Stone and Winter (1987), risk can be conceptualized as an expectation of loss. Among them, consumer can face the risk of future opportunity loss (Zikmund \& Scott, 1974), financial loss, physical loss, time loss and psycho-social loss (Mitchell, 1999).

When facing a risky situation, consumers engage in risk reduction strategies in order to better deal with it. Kasperson et al. (1988) illustrated the possible underestimation of risk perception by a number of well-known risky behaviors such as indoor radon, smoking, driving without seat belts, or eating highly carcinogenic aflatoxins in peanut butter. They call this distortion in perception as a social attenuation of the risk, which leads to an under-response as a consequence.

Recently, the literature suggested that hope can be one factor which influences perceived risk (MacInnis \& Chun, 2007; Snyder 2000). First, it is important to contextualize risk in hoped for situations: every uncertain situation involves a certain degree of risk, because there is always the risk of not achieving the desired outcome. Because hope only exists for uncertain situations, it is always related to risk. However, hope seems to lead people to run the involved risk (Averill et al., 1990), while fear would prevent them to do so (Bovens, 1999). People may decide to run the risk because they do not perceive it as too high, if compared to not hoped-for situations. For example, Hopfensitz (2006) found that hope predicted risk preferences in investment decisions. Subjects in Weber, Blais, 
and (2002) study reported highly beneficial situations from five different domains to be less risky than less beneficial ones, unlike most everyday situations in which risk and benefits are positively correlated. The explanation may be that such perception is affected by affective evaluations (Alhakami \& Slovic, 1994), and subjects' hope to get the benefits may be lowering the perceived risk of the high beneficial situations.

Risky behaviors may be related to a distortion in perceived risk in at least six ways. First, when searching for congruent information, people may ignore information pointing to the likelihood of negative consequences. So, high levels of hope may lower the perception of risks that a purchase or consumption process might involve (MacInnis \& Mello, 2005). This process has been found to happen for positive emotions in general, which reduce perceived risk if compared to negative emotions (Chaudhuri, 2002). For instance, people believe a medical treatment to be riskier when their emotions are negative rather than positive (Bowen et al., 2003). If hope could be considered a positive emotion or could evoke positive emotion, it would seem reasonable to infer that higher levels of hope lead to reduced perceived risk. Second, defense mechanisms lead people to only pay attention to non-risky decisions aspects; e.g. a person who hopes to lose weight may ignore the side effects information displayed on a medicine label (MacInnis \& Mello, 2005). Third, because people tend to rely more on information which is congruent to their initial beliefs they are more likely to terminate the process of searching for information earlier when the information found supports a desired conclusion than when it does not (Edwards \& Smith, 1996). Thus, people high in hope may look for less information to avoid finding incongruent information; consequently they are led to believe that there is no incongruent information to be found. Fourth, if risk information is processed, one is likely to counterargue this information, to search for more congruent information (Nenkov et al., 2009), or to change her/his own acceptance criteria (e.g. a person who hopes to heal a disease may tell him/herself that a medical treatment is not that painful). Joining all these processes, negative consequences seem less likely. Fifth, hope brings to mind favorable images (MacInnis \& Price, 1987), which can reduce the perception of consequence severity. Thus, because these negative images are less latent, they seem less likely to happen, due to the fact that people tend to place too much weight on highly salient data. Finally, Almeida (2010) found that women who strongly hope to look more attractive perceive plastic surgery as less risky than women whose hope is weaker. In other words, when one has a high level of hope, her/his wish for achieving the desired goal can be so strong that running any risks may seem worthwhile.

So, hope seems to be a predictor of perceived risk, in terms that high hope people would perceive less risk compared to low hope ones. However, such a relationship is still not clear in the literature. In this article we focus on the perception of financial risk (from now on we use the term perceived risk to mean perceived financial risk), which occurs when there is some monetary cost in the transaction, and we hypothesize that:

H1: The higher the level of hope, the lower the perceived financial risk.

\section{Hope and propensity for indebtedness}

Consumer financial decisions involve a number of psychological, physic and social values, many of them rooted in feelings and emotions (Vitt, 2004). Some of them can diminish precautions to maintain financial balance. For example, a person who has unrealistic expectations about future earnings is more prone to get indebted (Norvilitis, Szablicki, \& Wilson, 2003). In Fleming (2008), respondents stated that they would get indebted to achieve a goal which would allow a dream to come true. When hope was high, the information search process was simple, coming to an end when the expected result appeared to be possible.

One of the risk domains affected by hope is the economic domain (MacInnis \& Chun, 2007). Actually, hope may be an antecedent of risky behaviors such as gambling (Clotfelter \& Cook, 1989). Davies and Lea (1995) hypothesized that college students accumulate debt because of a belief that their current financial situation is temporary, so students' expectations are that as soon as they 
graduate, income will increase and debt will decrease. But maybe it is not only expectations that are playing a major role in propensity for indebtedness, but hope as well. Also, hope for a long and healthy life can be playing a role in affecting savings behaviors of young adults, since people may fail to imagine that they may not be healthy and underestimate costs of care arrangement for older adults, which results in not enough effort to save money for the future (Vitt, 2004). Indeed, people tend to underestimate their difficulties in the future, which is called the credit card effect. The credit card usage creates a false idea, in which one does not feel the sacrifice of losing his/her money, given that the payment will only happen in the future (Block-Lieb \& Janger, 2006).

When one hopes to achieve an important goal, s/he produces pathways, which are mental plans about what to do to achieve this goal. Because many goals are achieved by consuming some products (MacInnis \& Mello, 2005), purchasing them can become an important pathway. When the product is expensive, being able to purchase it may become another goal, which we call a purchase goal, and getting indebted may become a feasible personal strategy. Hope brings a person to action and getting indebted to purchase an expensive goal may become one of these actions. This explanation is consistent with the motivational character of hope.

Obviously, contracting debts is not the only pathway to achieve the goal of buying an expensive product (or service), since possible pathways include saving the money and postponing the purchase. But because there is only hope when the goal is important, it is possible that one might not want to wait to achieve it. So, we hypothesize that:

H2: The higher the level of hope, the higher the propensity for indebtedness.

\section{Perceived risk and propensity for indebtedness}

Inability to predict what can happen to a person's life has been proposed as a major explanation for financial problems (Raijas, Lehtinen, \& Leskinen, 2010). When one has lower perceived risk, s/he is less likely to take protective actions (Brewer, Weinstein, Cuite, \& Herrington, 2004), which would prevent her/him from becoming indebted. Even though this relationship seems intuitive, there is also evidence that there are some circumstances in which an increase in perceived risk is followed by a decrease in preventive behaviors (Temoshok et al., 1987), contrary to what may be predicted. The reason behind it is that when some risk is perceived as too high, people may feel helpless about it, which, in turn, decreases intentions to behave adaptively (Maddux \& Roggers, 1983).

Some studies failed to find a relationship between perceived risk and risky behaviors. For example, there was little support for a relationship between perceived risk and seatbelt usage in Stasson and Fishbein (1990); main conclusions were that perceived risk only affects behavior through subjective norms and attitudes. Weinstein (1984) argued that people seem to be able to recognize causes and consequences of risky situations when they are lived by other people, but are much less likely to recognize the relationships between their own actions and the risks they run.

Risk perception and attitude toward risk are different constructs (Weber et al., 2002), which means that a person can run a risk for two different reasons: because s/he underestimates the perceived risk, or because s/he underestimates the perceived benefit of the outcome (Weber \& Milliman, 1997; Weber et al., 2002; Yates \& Stone, 1992). Thus, when investigating the relationship between perceived risk and propensity for indebtedness, there is also the possibility that different people will perceive a given situation as equally risky, but for some the benefits are worthwhile and they are willing to engage in this behavior, while others, who are more risk averse, may see the benefits as less appealing (Conchar, Zinkhan, Peters, \& Olavarrieta, 2004; Farley, 1986).

Since it is not clear whether there actually is a relationship between perceived risk and risky behaviors, the prediction that a decrease in perceived risk leads to an increase to the likelihood of getting indebted is a matter of investigation. When investigating the relation between perceived risk and propensity for indebtedness, there is also the possibility that different people will perceive a given situation as equally risky, but for some the benefits are worthwhile and they are willing to engage in 
this behavior, while others may see the benefits as less appealing (Conchar et al., 2004). We hypothesize that

H3: The lower the perceived risk, the higher the propensity for indebtedness.

Next we present the two empirical studies testing the relationship between hope, perceived risk and propensity for indebtedness.

\section{Study 1}

\section{Method}

The experimental design was a 2 (high vs. low hope) X 2 (high vs. low risk) factorial betweensubjects. The dependent variables are perceived risk and the propensity for indebtedness. Seven hundred and sixty people were invited by e-mail to participate in the experiment, based on a list of former MBA students from all over Brazil, using the snow ball technique for sampling, from August to September 2010. One hundred and thirty-three accepted (18\% response rate). Subjects were randomly assigned to one of the four pre-tested conditions.

Hope was manipulated by using a projective technique in which subjects put themselves in an imagined person's life so this third person's hope could be effectively manipulated. Instructions in the high hope scenario were about Paul, a hopeful and hard working 30-year man whose dream was to buy a condominium, in order to start a new life of independence and freedom. Because he just graduated from college and lives frugally, he strongly believes that can he save the money previously allocated for tuition, allowing him to pay installments to finance a small condominium. Deeply inside, he is completely convinced that he wants and needs this condominium and he believes now is the right time. Instructions in the low hope scenario were about John, a hopeless and hard working 30-year man thinking about the possibility of buying a condominium. He just graduated from college and although he lives frugally he believes his savings are not enough to pay installments to finance a small condominium. Deeply inside, he is not convinced that he wants this condominium because he is not sure it is the right time.

The high hope situation was consistent with the theory, showing a person who had a positive and important goal for the future and showed some degree of belief that this goal could possibly be achieved. The low hope situation, on the other hand, showed that the same goal was not that important and the belief that it could possibly be achieved was weaker. In the pre-test, 40 subjects read the situation and evaluated the character's hope by agreeing to the following statement: Paul/John has high hopes to buy the condominium $(1=$ totally disagree; $7=$ totally agree $)(\mathrm{p}<0.005$; Kruskal Wallis test). Because the risks manipulated were associated with the purchase of a condominium (risk related to the product class itself), they were inherent risks (Kim \& Lee, 2012).

Risk was manipulated by showing different mortgage payment options for each condition. The main differences were: (a) value of each monthly payment (high vs. low proportion of character's monthly salary); (b) finance conditions (12\% annually adjustable interest rate for 60 months vs. $8 \%$ annually fixed interest rate for 360 months); and (c) character's occupation (riskier: free-lancer vs. safer: civil servant). To check differences in subjects' perception of the riskiness of each choice, we ran a pre-test with 40 subjects (hope was not manipulated in this pre-test), where they read the situation and evaluated its riskiness by agreeing with the following statement: Paul runs a lot of risk by getting this loan $(1=$ totally disagree; $7=$ totally agree $)$. There was a significant difference between high (mean=33.52) and low risk (mean=21.35) $(\mathrm{P}<0.005$; Kruskal Wallis test).

After reading the situations, subjects answered a questionnaire about: hope and perceived risk of getting indebted and not being able to pay it back (manipulation check); character's propensity for 
getting indebted to purchase an condominium and character's perceived risk for getting indebted and not being able to pay it back (dependent variables). We measured hope based on Poels and Dewitte (2008) by the following statements: (a) Paul/John has high hopes to buy the condominium, (b) Buying an condominium is important to Paul/John, and (c) Paul/John believes he will be able to buy the condominium $(1=$ totally disagree; $7=$ totally agree $)$. The original scale measured three hope characteristics based upon subjects' opinions of advertising, by using the following statements: (1) The ad makes me hopeful; (2) - the product of the ad is important to me; and (3) - it is uncertain that the product of the ad will work. Their objective was to capture the following dimensions: (a) hope itself, (b) importance, and (c) uncertainty. Initially, we decided to use the same questions by just adapting them to the new situation. However, after conducting a pre-test with twenty subjects (different from the stimuli's pre-test), we noticed that uncertainty was a dimension which was difficult to measure. Instead of understanding the difference between certain versus uncertain, subjects understood the question as likely to happen versus unlikely to happen. For this reason, instead of measuring uncertainty, we decided to include a measure of belief, which is a characteristic of the concept of hope used here. Here, the dimensions of hope and importance were maintained, and the scale showed high reliability (Cronbach's Alpha of .85).

To measure propensity for indebtedness, respondents were asked to rate how much they believed Paul/John would end up getting this loan (1 = no way!; 7 = for sure!).

Because the scales found in the literature for measuring perceived risk (e.g. Eroglu \& Machleit, 1990; Stone \& Gronhaug, 1993) were not appropriate for the specific situation, we created the items based on qualitative research. Thus, to measure respondent's perceived risk, respondents were asked to show their level of agreement to the following statements: (a) Paul/John runs a lot of risk by getting this loan; (b) The probability that Paul/John will not afford all month payments is high; (c) It is likely that Paul/John will have unexpected expenses during the loan period; (d) It is likely that Paul/John loses his main income source during the loan period $(1=$ totally disagree; $7=$ totally agree). The indicators were chosen due to the fact that they show some common negative events that can happen when a person gets a mortgage loan. Measuring perceived risk by asking the likelihood of negative events is a way that has been used by a number of studies (e.g. Chen, 2007; Kovacs \& Farias, 2004; Peter \& Tarpey, 1975). The scale showed high reliability (Cronbach's Alpha of .72).

To measure the character's perceived risk, subjects were asked whether they think that the character would perceive the risk he was running by getting the loan: (a) Paul/John perceives the risk of getting this loan; (b) Paul/John thinks it is likely that he will not afford all month payments; (c) Paul/John thinks about the possibility of having unexpected expenses during the loan period; (d) Paul/John thinks about the possibility of losing his main income source during the loan period $(1=$ totally disagree; 7 = totally agree). This scale showed high reliability (Cronbach's Alpha of .77).

\section{Results}

The characteristics of the convenience sample are: mean age (34.2 years), 50\% male and most of them (59\%) have a monthly income above $\mathrm{R} \$ 7,650.00$. No significant differences across characteristics were observed. In the manipulation check, hope $(\alpha=0.85)$ and perceived risk $(\alpha=0.77)$ were perceived as different in the two manipulated situations $(\mathrm{p}<0.001)$. Supporting hypothesis 1 , an ANOVA of character's perceived risk $(\alpha=0.75)$ revealed a main effect between high and low hope conditions $(M=12.66$ vs. 18.31 , respectively; $\mathrm{F}(1,133)=54.49 ; \mathrm{p}<0.001)$. It means that respondents who imagined a character (Paul/John) having stronger levels of hope said he was less likely to perceive the risks associated with getting a mortgage loan than respondents who imagine a character having weaker levels of hope. Supporting hypothesis 2, an ANOVA of propensity for indebtedness revealed a main effect between high and low hope conditions $(M=5.51$ vs. 3.48, respectively; $\mathrm{F}(1,133)=51.40 ; \mathrm{p}<0.001)$. It means that respondents who imagined a character having stronger levels of hope said that he was more prone to accept the loan than respondents who imagine a character having weaker levels of hope. Supporting hypothesis 3, an ANOVA of propensity for indebtedness revealed a main effect between high and low perceived risk conditions $(M=4.17$ vs. 
5.02 , respectively; $\mathrm{F}(1,133)=6.80 ; \mathrm{p}<0.001)$. When the situation seemed less risky, respondents stated that the character would be more prone to get the loan. There was no interaction between hope and perceived risk on propensity for indebtedness, and no interaction between hope and perceived risk on the character's perceived risk ( $p>0.05$ ). Figure 1 illustrates the main effects of hope and perceived risk on propensity for indebtedness.

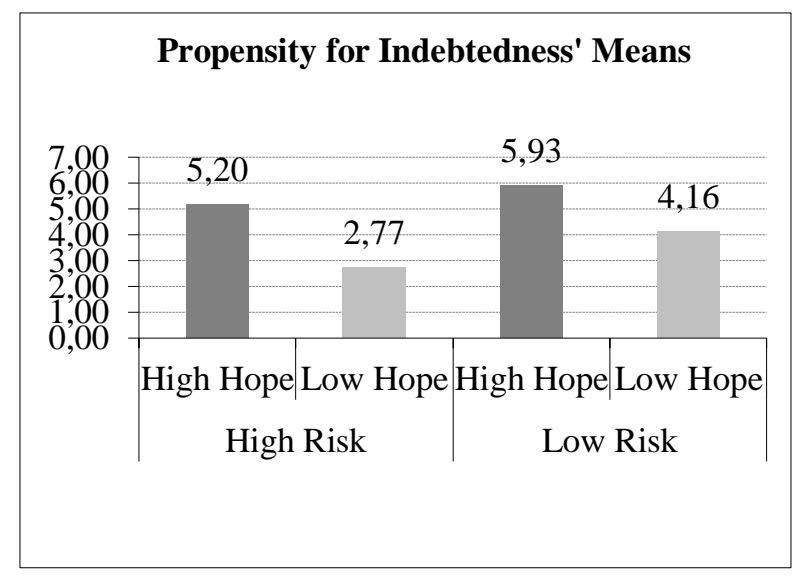

Figure 1. Propensity for indebtedness' Means for the Four Experimental Conditions.

As mentioned before, perceived risk was measured twice. First, the respondent's perceived risk was measured for the manipulation check. Then, the character's perceived risk was measured as a dependent variable, being influenced by hope. For this reason, it is important to evaluate whether the manipulation of risk affected the character's perceived risk. Character's perceived risk was not significantly different in high risk $(M=15.11)$ vs. low risk $(M=15.5)$ conditions $(\mathrm{F}(1,133)=0.18$; $\mathrm{p}>0.05$ ). It suggests that the respondents evaluated the risk in a rational way, but when they projected themselves into the character's situation, they allowed hope to interfere with their perception of the risk.

\section{Study 2}

\section{Method}

To summarize hypotheses 1, 2 and 3, a theoretical model is presented in Figure 2, demonstrating the proposed relationships among the three variables. The purpose of this study is to test the relationship among those variables in a real consumer context, in addition to increasing external validity of the findings from Study 1.

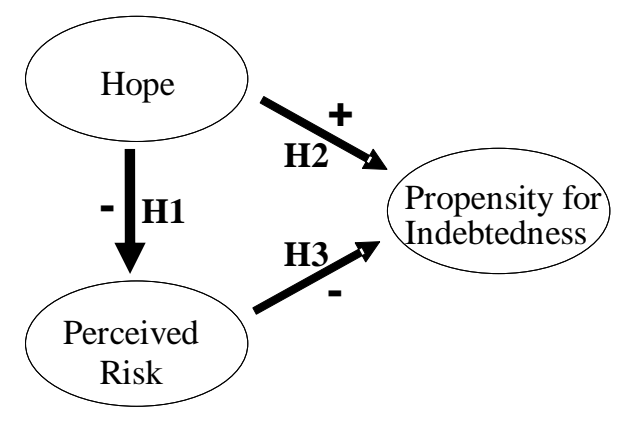

Figure 2. Proposed Model of the Role of Hope on Perceived Risk and Propensity for Indebtedness. 
Some prior in-depth interviews with undergraduate students of a large private business school brought graduating from college as a hoped for situation, which would lead to a major goal of building a successful career and, as a consequence, finding the job of their dreams. This situation may be capable of provoking indebtedness, because some students may not afford to pay their tuition fee. As a result, indebtedness may become a risky situation.

Subjects consisted of two hundred seventy-three Brazilian university students from a private university that charges a monthly tuition around $\mathrm{R} \$ 400.00$, who answered the online questionnaire in October and November, 2010. Two hundred sixty-four students answered all of the questions (response rate of 97\%), and incomplete responses were excluded from the analysis. We used Structural Equation Modeling for data analysis (software AMOS 19.0.0) (maximum likelihood estimator).

To measure hope, we used a scale from Vieira (2008), the only one developed in Portuguese and tested with Brazilian consumers, as seen in Table 1. It is multidimensional in nature (dimensions: importance, perceived possibility, goal congruency). Originally, this scale was developed for the situation of hope of losing weight, and we adapted it to represent the context of hope of finding the dream job after graduating from college.

Table 1

Indicators of the Hope Scale

\begin{tabular}{llll}
\hline Dimension & \multicolumn{1}{c}{ Indicators } & Dimension & \multicolumn{1}{c}{ Indicators } \\
\hline Importance & $\begin{array}{l}\text { (IM1) Achieving the job of my } \\
\text { dreams is important to me }\end{array}$ & $\begin{array}{l}\text { Goal } \\
\text { Congruency }\end{array}$ & $\begin{array}{l}\text { (C1) Achieving the job of my dreams is } \\
\text { part of my life's greatest goals }\end{array}$ \\
\hline Importance & $\begin{array}{l}\text { (IM2) To be fully satisfied, I need to } \\
\text { achieve the job of my dreams }\end{array}$ & $\begin{array}{l}\text { Goal } \\
\text { Congruency }\end{array}$ & $\begin{array}{l}\text { (C2) I need to achieve the job of my } \\
\text { dreams to consider myself a happy } \\
\text { person }\end{array}$ \\
\hline Importance & $\begin{array}{l}\text { (IM3) To achieve the job of my } \\
\text { dreams, it is imperative to graduate } \\
\text { from university }\end{array}$ & $\begin{array}{l}\text { Goal } \\
\text { Congruency }\end{array}$ & $\begin{array}{l}\text { (C3) Achieving the job of my dreams is } \\
\text { an ideal in my life }\end{array}$ \\
\hline Perceived & (PP) From 0\% to 100\%, how sure are you that you will achieve the job of your dreams? \\
\hline Possibility & & &
\end{tabular}

Even though they are part of the concept of hope, some dimensions could not be included in the questionnaire. Uncertainty was removed from the scale after the pre-test, since questions such as I am not sure that I will achieve the job of my dreams did not reflect uncertainty, since people who strongly believed in this possibility totally disagreed with this statement. Writing the same statement as a reverse question (e.g. I am 100\% sure that I will achieve the job of my dreams) resulted in the same kind of interpretation. However, because this situation (achieving the dream job) is in the future, it is implicit that it is uncertain. The dimension future orientation was also removed for the same reason. 
Table 2

Indicators of Propensity for Indebtedness and Perceived Risk Scales

\begin{tabular}{ll}
\hline \multicolumn{1}{c}{ Propensity for indebtedness } & \multicolumn{1}{c}{ Perceived risk } \\
\hline $\begin{array}{ll}\text { (PE1) Contracting debt to pay the university's tuition } \\
\text { is worthwhile }\end{array}$ & \begin{tabular}{l} 
(PR1) Going to university is a very high investment. \\
\cline { 2 - 2 }
\end{tabular} \\
$\begin{array}{ll}\text { (PR2) Going to university requires a lot of sacrifices } \\
\text { (PE2) I prefer to get a loan instead of waiting to save } \\
\text { money to pay the university tuition }\end{array}$ & $\begin{array}{l}\text { (PR3) After all considerations, I think going to } \\
\text { university could be a mistake. }\end{array}$ \\
\hline $\begin{array}{ll}\text { (PE3) I would be willing to compromise a significant } \\
\text { part of my future income to pay the installments of } \\
\text { my university tuition loan }\end{array}$ & $\begin{array}{l}\text { (PR4) I feel that going to university could bring me } \\
\text { negative consequences. }\end{array}$ \\
\cline { 2 - 2 } & $\begin{array}{l}\text { (PR5) I am afraid of not being able to pay my } \\
\text { university tuition. }\end{array}$ \\
\hline $\begin{array}{l}\text { (PE4) I find it natural when people are indebted in } \\
\text { order to pay their university tuition }\end{array}$ & $\begin{array}{l}\text { (RI) The decision to go to university involves high } \\
\text { risk. }\end{array}$ \\
\cline { 2 - 2 } & (PR6) Going to university is a very high investment. \\
\hline
\end{tabular}

Propensity for indebtedness was adapted from Ribeiro, Vieira, Santos, Trindade, and Mallmann (2009), who measured attitudes toward indebtedness. The adaptations were made: (a) to contextualize the statements in the given situation; and (b) to measure not only attitudes, but also the willingness to engage in this behavior. Perceived risk was adapted from Eroglu and Machleit (1990) and Stone and Gronhaug (1993). All variables were measured in a 7-point Likert scale (totally disagree; totally agree), and their indicators are displayed in Table 2.

\section{Results}

The characteristics of the convenience sample are: gender ( $62.1 \%$ females and $37.9 \%$ males), age $(72.6 \%$ between $17-25 ; 21.9 \%$ between $26-35$; and $5.5 \%$ between $36-45$ years old), undergraduate major (81.3\% in business administration; $10.3 \%$ in international business; and $8.4 \%$ in other courses). The majority of respondents (38\%) are enrolled on their third year of university.

After exploratory factor analysis for each variable, we found that perceived risk's indicators loaded on three factors, showing construct's multidimensionality. The indicators PP, HO, and IM3 were dropped from further analysis since they did not load on any factor.

Hope was measured by five items (IM1, IM2, C1, C2 and C3; propensity for indebtedness was measured by four items (PE1, PE2, PE3 and PE4) and perceived risk was measured by four items (PR1, PR2, PR5 and RI). All three variables had all standardized regression weights higher than 0.50 . For perceived risk, the best fit was achieved by a second-order model, having two dimensions (factor 1: sacrifice; factor 2: financial risk), according to the multidimensionality of this variable (Johnson et al., 2008). Indexes for the measurement model and reliability of the three variables are displayed in Table 3. The final model is displayed in Figure 3. 
Table 3

Indexes for the Measurement Model and Reliability of the Three Variables

\begin{tabular}{|c|c|c|c|c|c|c|c|c|}
\hline \multirow{2}{*}{ Variable } & \multirow{2}{*}{$\begin{array}{l}\text { Composite } \\
\text { Reliability }\end{array}$} & \multirow{2}{*}{$\alpha$} & \multicolumn{6}{|c|}{ Indexes for the measurement model } \\
\hline & & & $\chi^{2}$ & $\chi^{2} / \mathrm{DF}$ & RMR & GFI & RMSEA & CFI \\
\hline Hope & 0.76 & 0.79 & 5.880 & 2.940 & 0.003 & 0.099 & 0.086 & 0.990 \\
\hline $\begin{array}{l}\text { Propensity } \\
\text { for } \\
\text { indebtedness }\end{array}$ & 0.74 & 0.73 & 1.447 & 0.724 & 0.002 & 0.997 & 0.000 & 1 \\
\hline Perceived risk & $\begin{array}{l}\text { Factor 1: } 0.70 \\
\text { Factor } 2: 0.56\end{array}$ & $\begin{array}{l}0.70 \\
0.53\end{array}$ & 4.018 & 2.009 & 0.025 & 0.992 & 0.062 & 0.986 \\
\hline
\end{tabular}

$\chi 2$ : Chi-Square; $\chi 2 /$ df: ratio of Chi-Square and degrees of freedom; RMR: standardized root mean square residual; GFI: goodness-of- fit index; RMSEA: root mean square error of approximation; CFI: comparative fit index.

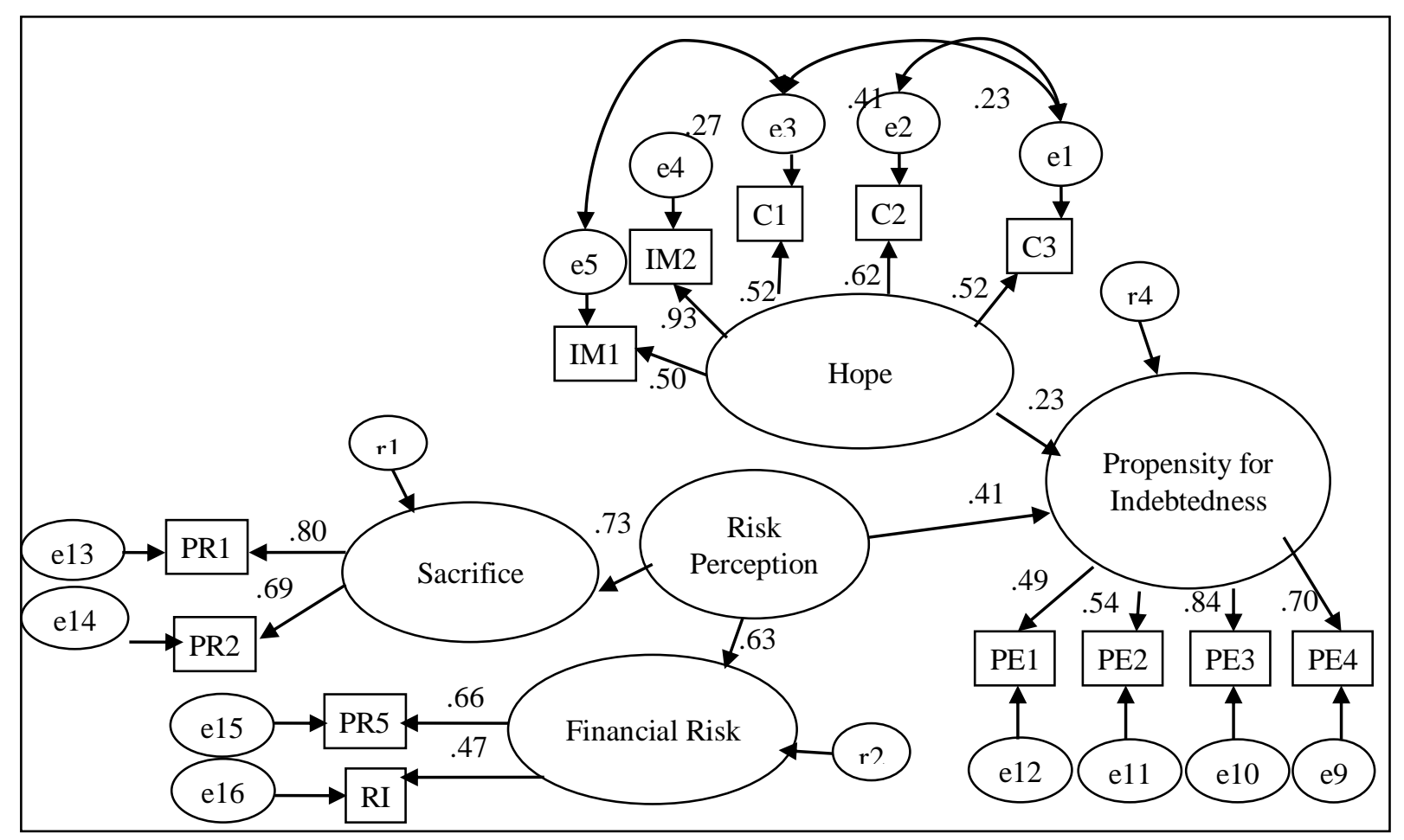

Figure 3. Final Structural Model.

In the final model all estimates achieved significance, and because the relationship between hope and perceived risk did not achieve significance, it was omitted from the model. After that, the inspection of modification indices did not suggest any misspecification of the final model. Table 4 displays the goodness-of-fit indexes for the structural model. 
Table 4

Goodness-of-fit Indexes for the Structural Model

\begin{tabular}{cccccccc}
\hline \multicolumn{7}{c}{ Goodness-of-fit indexes for the structural model } \\
\hline df & $\chi^{2}$ & $\chi^{2} / \mathrm{DF}$ & RMR & GFI & AGFI & RMSEA & CFI \\
\hline 59 & 76.999 & 1.305 & 0.051 & 0.958 & 0.935 & 0.034 & 0.978 \\
\hline
\end{tabular}

$\chi 2$ : Chi-Square; $\chi 2 / \mathrm{df}$ : ratio of Chi-Square and degrees of freedom; RMR: standardized root mean square residual; GFI: goodness-of- fit index; AGFI: adjusted goodness-of-fit index; RMSEA: root mean square error of approximation; CFI: comparative fit index

Hypothesis 1 was not supported, suggesting that hope does not influence perceived risk. This finding supports the idea that getting indebted may be worthwhile. An alternative explanation for this finding is that because all subjects actually are university students, their perceived risk about going to university may already be low if compared to people who do not go to college. Hypothesis 2 was supported $(\mathrm{p}<0.005$; standardized regression weight $=0.233)$, so subjects who showed willingness to get indebted to pay for their studies are the ones who showed to have more hope. However, it does not mean that they see it as a risk-free decision.

In other words, the model suggests that the higher the subjects' hope for achieving the job of their dreams, the higher their willingness to get indebted to pay for their tuition. The results provide empirical support to Fleming's (2008) qualitative finding. Therefore, it is possible to suppose that getting indebted may be seen as a pathway for affording college tuition, which, in turn, is a pathway for achieving a good job, in accordance with Snyder (2000).

The structural model showed a significant positive relationship between perceived risk and propensity for indebtedness $(\mathrm{p}<0.001$; standardized regression weight $=0.351)$ (hypothesis 3 predicted a negative relation between those variables). It means that subjects who perceived more risks in going to college are the ones who showed more willingness to get indebted. We found three alternative explanations for this finding. First, students who can afford to pay for their studies may not find this a risky decision and may not have been able to see themselves in a situation in which they would get indebted. We did not get this information from the sample, so it could be verified in future research. Second, the fact that all subjects are actually university students may have influenced the results, since individuals who perceive going to college as a risky choice might not become undergraduate students and thus weren't included in the sample. Third, when some risk is perceived as too high, people may feel helpless about it, which in turn decreases intentions to behave adaptively (Maddux \& Roggers, 1983), according to other findings in which an increase in perceived risk is followed by a decrease in preventive behaviors (Temoshok et al., 1987).

\section{Final Remarks}

The first study experimentally investigated the impacts hope plays on perceived risk and propensity for indebtedness, and the influence of perceived risk on propensity for indebtedness. Our results in this study confirm that hope influences propensity for indebtedness. In accordance to Fleming (2008), when the character showed to have a higher level of hope, subjects believed they would be more prone to get indebted than when they showed a lower level of hope. The reason behind this could be either a decrease in perceived risk or a reflection that in order to achieve the desired goal running high risks might be worthwhile.

Hope influenced perceived risk, in agreement with MacInnis and Mello (2005). Specifically, when subjects faced the high hope scenario, they agreed that the character perceived less risk in 
getting the loan, compared to when subjects faced the low hope scenario. Hence, we can suppose that a decrease in perceived risk could have contributed to an increase in the likelihood of getting indebted.

This study also showed evidences that perceived risk may influence the propensity for indebtedness. When the perceived risk was lower, subjects were more prone to agree that the character would get the loan. These findings are consistent with the theory that perceived risk is an antecedent of behavior (Brewer et al., 2004). Although both hope and perceived risk seemed to influence consumers' propensity for indebtedness, we did not find a significant interaction between them.

Our results in this study expand the current literature in three ways. First, we provided empirical evidence that hope works as an antecedent of consumer's propensity for indebtedness. Second, we suggested that one of the reasons for getting indebted when hope is high is a decrease in perceived risk. Finally, results supported that the three constructs (hope, perceived risk, and propensity for indebtedness) can be integrated into a single theoretical model, which is the focus of Study 2.

The second study investigated the impacts hope plays on perceived risk and propensity for indebtedness through path analysis, in a more realistic context as compared to the first study. Specifically, the goal was to investigate whether hope for a better future would lead to a decrease in perceived risk and, as a consequence, to an increase in propensity to become indebted. The level of subjects' hope to achieve the job of their dreams influenced an increase in the propensity to get indebted in order to afford college tuition, in accordance with the first study and with Fleming (2008). Going to college may be seen as a major pathway to achieve this hoped-for goal.

However, this study failed to find a significant relationship between hope and perceived risk, suggesting that the level of students' hope to achieve the job of their dreams wasn't sufficient to make the decision to go to university seems less risky. The reason may be that they think that running this risk is worthwhile, or because all of them have already decided to go to college, apparently independent on their level of hope. In other words, if hope really is an antecedent of perceived risk, less hopeful people may have not being included in the sample because of their decision of not going to university. Unlike what was predicted, this study found a positive relationship between perceived risk and propensity for indebtedness. A possible reason is that people who said that going to college is a risky choice are the ones who already considered getting indebted to pay the university's tuition. It may be possible that their income level is affecting both their perceived risk and propensity for indebtedness, which is a matter of further investigation.

Both studies offered support to the hypothesis that hope influences propensity for indebtedness. Specifically, higher levels of hope predicted an increase in the character's propensity to accept the mortgage loan, independent of actual risks, such as fixed installments or income stability. In addition, higher levels of hope predicted an increase in the propensity college students have to get indebted to pay for their studies. Findings are consistent with the idea that getting indebted would be a feasible pathway (Snyder, 2000) to achieve an important goal. Consistent with MacInnis and Chun (2007) and MacInnis and Mello (2005), purchase and consumption appeared to be the goal per see (buying a condominium) or the means to achieve the main goal (going to university is a means to achieve a good job).

However, the two studies have shown conflicting evidences regarding the impacts of hope on perceived risk and of perceived risk on propensity for indebtedness. Instead of reducing perceived risk, hope leads subjects to believe that running any risks would be worthwhile (Bell, 1995; Chen, 2007), as the benefit of achieving a good job would be evaluated as higher than the risk of not being able to pay the installments (Weber et al., 2002). Another possibility, which has not yet been investigated, is that situational aspects moderate the influence of hope on perceived risk and of perceived risk on propensity for indebtedness. Here, the hope for purchasing an condominium negatively influenced the perceived risk of a mortgage loan, while the hope for having a better future was not sufficient to negatively influence the perceived risk of going to college. 
This research offers some methodological contributions, empirically investigating the relationship among hope, perceived risk and propensity for indebtedness. Because hope can be stimulated by advertising (MacInnis \& Chun, 2007), this research shows an opportunity for increases in sales by stimulating installment payments or consumer credit acquisition. Also, our findings suggest that consumers may underestimate the risks of getting indebted or think that these risks are worth running, when they strongly hope for an acquisition. For this reason, managers may develop and apply mechanisms to prevent themselves from selling goods to people who might overestimate their ability to pay. In addition, our results have implications for public policies: an over-indebted population causes a number of negative consequences for the society, from an increase in prices to economic crisis. Understanding the impact of consumer hope on propensity for indebtedness sheds light on the development of mechanisms to prevent over-indebtedness. Finally, when consumers understand the underlying mechanisms behind their indebtedness behavior, they can develop better strategies for achieving financial balance.

Even though this study has provided new thoughts, several limitations should be voiced, and overcome in future research. First, while the projective approach has shown to be appropriate for study 1 , respondents may fail to imagine themselves in the character's situation and answered the questions thinking about how a third person would behave instead of him/herself. Manipulating respondents' own hope level looks fruitful for future studies. Second, there have been only a few trials of measuring hope in consumer behavior (exceptions are Almeida, 2010; Chen, 2007; Mello, MacInnis, \& Stewart, 2007; Nenkov et al., 2009; Poels \& Dewitte, 2008; Wang, 2007), each of them using different scales. Consequently, it may be difficult to compare findings among studies (marketing literature needs a better measure for hope). Third, concerning study 2, there are other variables that could cause effects on perceived risk and propensity for indebtedness, such as personality traits, attitude (e.g. risk propensity or aversion), indebtedness and past experience. Fourth, using a student sample was not sufficient to offer evidence of the relationship between hope and perceived risk and between perceived risk and propensity for indebtedness. It would be ideal to include in the sample people with the same demographic characteristics, who decided not to go to university. Finally, sample selection procedure (convenience sample) limits the generalizability of the two studies.

Future studies could investigate the role of income as a moderator of perceived risk and propensity for indebtedness, check whether there are any differences in propensity to become indebted and real indebtedness, and whether is possible that the risk of getting indebted is seen as too high and able to inhibit preventive behaviors.

An alternative explanation for the influence of hope on propensity for indebtedness is that it is not due to a decrease in perceived risk, but due to a feeling that running any risks may be worthwhile. This idea was presented by MacInnis and Mello (2005) and should be investigated further. The reason for getting indebted for high hope people (a reduction in perceived risk or the feeling that running risks is worthwhile) should be investigated further: if both mechanisms can happen as a consequence of hope, when each one is more likely to operate, and what are the reasons? If hope really decreases perceived risk, it is not clear whether it decreases the perception of the likelihood that a negative outcome could happen or perception of the severity of its consequences. Such issues have not been investigated yet and would increase our knowledge about how people make purchase decisions.

\section{Received 20 November 2011; received in revised form 15 August 2012.}

\section{Note}

\footnotetext{
${ }^{1}$ This article was presented at Enanpad 2011 and received an indication to participate in BAR's Fast Track.
} 


\section{References}

Alhakami, A. S, \& Slovic, P. (1994). A psychological study of the inverse relationship between perceived risk and perceived benefits. Risk Analysis, 14(6), 1085-1096. doi: 10.1111/j.15396924.1994.tb00080.x

Almeida, A. R. D. (2010). Esperança: construção e teste de um modelo teórico da sua influência no processo de compra do consumidor de cirurgia plástica estética (Tese de doutorado). Universidade de São Paulo, São Paulo, SP, Brazil.

Almeida, A. R. D., \& Botelho, D. (2008). Antecedentes da satisfação no setor imobiliário. Revista de Administração de Empresas, 48(2), 11-23. doi: 10.1590/S0034-75902008000200002

Averill, J. R., Catlin, G., \& Chon, K. K. (1990). The rules of hope. New York: Springer-Verlag.

Bauer, R. A. (1960). Consumer behavior as risk taking. In R. S. Hancock (Ed.), Dynamic marketing for a changing world (pp. 389-98). Chicago: American Marketing Association.

Belk, R., Ger, G., \& Askegaard, S. (2003). The fire of desire: a multi-sited inquiry into consumer passion. Journal of Consumer Research, 30(3), 326-351.

Bell, D. E. (1995). Risk, return, and utility. Management Science, 41(1), 23-30. doi: $10.1287 / \mathrm{mnsc} .41 .1 .23$

Bettman, J. R. (1973). Perceived risk and its components: a model and empirical test. Journal of Marketing Research, 10(2), 184-190.

Bloch, E. (1986). The principle of hope (N. Plaice, S. Plaice; P. Knight, Trans.). Cambridge, MA: MIT Press. (Original work published 1986)

Block-Lieb, S., \& Janger, E. J. (2006). The myth of the rational borrower: rationality, behavioralism and the misguided "Reform of banckruptcy law". Texas Law Review, 84(6), 1481-1565.

Bovens, L. (1999). The value of hope. Philosophy and Phenomenological, 59(3), 667-681.

Bowen, D. J., Helmes, A., Powers, D., Andersen, M. R., Burke, W., McTiernan, A., \& Durfey, S. (2003). Predicting breast cancer screening intentions and behavior with emotion and cognition. Journal of Social and Clinical Psychology, 22(2), 213-232. doi: 10.1521/jscp.22.2.213.22875

Brewer, N., Weinstein, N., Cuite, C., \& Herrington, J. (2004). Perceived risks and their relation to risk behavior. Annals of Behavioral Medicine, 27(2), 125-130.

Bruininks, P., \& Malle, B. F. (2005). Distinguishing hope from optimism and related affective states. Motivation and Emotion, 29(4), 327-355. doi: 10.1007/s11031-006-9010-4

Carver, C. S., Scheier, M. E, \& Weintraub, J. K. (1989). Assessing coping strategies: a theoretically based approach. Journal of Personality and Social Psychology, 56(2), 267-283.

Chaudhuri, A. (2002). A study of emotion and reason in products and services. Journal of Consumer Behaviour, 1(3), 267-279. doi: 10.1002/cb.72

Chen, S. Y. (2007). The impacts of advertising on information type, hope, and perceived risk on consumer behavior (Master's article). National Cheng Kung University, Taiwan.

Clotfelter, C. T., \& Cook, P. J. (1989). Selling hope: state lotteries in America. Cambridge: Harvard University Press. 
Conchar, M. P, Zinkhan, G. M., Peters, C., \& Olavarrieta, S. (2004). An integrated framework for the conceptualization of consumers' perceived-risk processing. Journal of the Academy of Marketing Science, 32(4), 418-436. doi: 10.1177/0092070304267551

Cutcliffe, J. R., \& Herth, K. A. (2002). The concept of hope in nursing: Its origins, background and nature. British Journal of Nursing, 11(12), 832-840.

Das, T. K., \& Teng, B. S. (1998). Between trust and control: developing confidence in partner cooperation in alliances. Academy Management Review, 23(3), 491-512. doi: 10.5465/AMR.1998.926623

Davies, E., \& Lea, S. E. G. (1995). Student attitudes to student debt. Journal of Economic Psychology, 16(4), 663-679. doi: 10.1016/0167-4870(96)80014-6

Day, J. P. (1991). Hope: a philosophical inquiry (Vol. 51). (Acta Philosophica Fennica). Helsinki: Hakapaino Oy.

Edwards, K., \& Smith E. S. (1996). A disconfirmation bias in the evaluation of arguments. Journal of Personality and Social Psychology, 71(1), 5-24.

Eroglu, S., \& Machleit, K. (1990). An empirical study of retail crowding: antecedents and consequences. Journal of Retailing, 66(2), 201-221.

Farley, F. (1986). The big T in personality. Psychology Today, 20(5), 44-52.

Fleming, M. C. N. C. (2008). O papel da esperança na compra de crédito pessoal em consumidores de baixa renda (Dissertação de mestrado). Faculdade de Economia e Finanças IBMEC, Rio de Janeiro, RJ, Brazil.

Hopfensitz, A. (2006). The role of affect in reciprocity and risk taking: experimental studies of economic behavior (Doctoral dissertation). University of Amsterdam, The Netherlands.

Horton, R. L. (1976). The structure of perceived risk: some further progress. Journal of the Academy of Marketing Science, 4(4), 694-706. doi: 10.1007/BF02729830

Jacoby, J., \& Kaplan, L. (1972). The components of perceived risk. In M. Venkatesan (Ed.), Proceedings of the Association for Consumer Research Annual Conference, Champaign, IL, USA, 3 .

Johnson, M. S., Sivadas, E., \& Garbarino, E. (2008). Customer satisfaction, perceived risk and affective commitment: an investigation of directions of influence. Journal of Services Marketing, 22(5), 353-362. doi: 10.1108/08876040810889120

Kasperson, R. E., Renn, O., Slovic, P., Brown, H. S., Emel, J., Goble, R., Kasperson, J. X. \& Ratick, S. (1988). The social amplification of risk: a conceptual framework. Risk Analysis, 8(2), 177188. doi: 10.1111/j.1539-6924.1988.tb01168.x

Kim, N., \& Lee, M. (2012). Other customers in a service encounter: examining the effect in a restaurant setting, Journal of Services Marketing. 26(1), 27-40. doi: $10.1108 / 08876041211199706$

Kovacs, M. H., \& Farias, S. A. (2004). Dimensões de riscos percebidos nas compras pela Internet. RAE-eletrônica, 3(2). Retrieved from http://www.scielo.br/pdf/raeel/v3n2/v3n2a13.pdf. doi: 10.1590/S1676-56482004000200013

Lazarus, R. S. (1999). Hope: an emotion and a vital coping resource against despair. Social Research, 66(2), 653-678. 
MacInnis, D. J., \& Chun, H. E. (2007). Understanding hope and its implications for consumer behavior: I hope therefore, I consume. Foundations and Trends in Marketing, 1(2), 97-189. doi: $10.1561 / 1700000005$

MacInnis, D. J., \& Mello, G. E. de (2005). The concept of hope and its relevance to product evaluation and choice. Journal of Marketing, 69(2), 1-14.

MacInnis, D. J., \& Price, L. L. (1987). The role of imagery in information processing: review and extensions. Journal of Consumer Research, 13(4), 473-492. doi: 10.1086/209082

Maddux, J. E., \& Roggers, R. W. (1983). Protection motivation and self-efficacy: a revised theory of fear appeals and attitude change. Journal of Experimental Social Psychology, 19(5), 469-479. doi:10.1016/0022-1031(83)90023-9

March, J. G., \& Shapira, Z. (1987). Managerial perspectives on risk and risk taking. Management Science, 33(11), 1404-1418. doi: 10.1287/mnsc.33.11.1404

Mello, G. E. de, MacInnis, D. J., \& Stewart, D. W. (2007). Threats to hope: effects on reasoning about product information. Journal of Consumer Research, 34(2), 153 161. doi: 10.1086/519144

Mitchell, V. W. (1999). Consumer perceived risk: conceptualisations and models. European Journal of Marketing, 33(1/2), 163-195. doi: 10.1108/03090569910249229

Moltmann, J. (1967). Theology of hope: on the ground and the implications of a Christian eschatology (J. W. Leitch, Trans.). New York: Harper and Row. (Original work published 1967)

Nenkov, G. Y., MacInnis, D. J., \& Morrin, M. (2009). How do emotions influence saving behavior? Center for Retirement Research, 9(8), 1-11.

Norvilitis, J. M., Szablicki, P. B., \& Wilson, S. D. (2003). Factors influencing levels of credit-card debt in college students. Journal of Applied Social Psychology, 33(5), 935-947. doi: 10.1111/j.1559-1816.2003.tb01932.x

Peter, J. P., \& Tarpey, L. Z. (1975). A comparative analysis of three consumer decision strategies. Journal of Consumer Research, 2(1), 29-37.

Poels, K., \& Dewitte, S. (2008). Hope and self-regulatory goals applied to an advertising context: promoting prevention stimulates goal-directed behaviour. Journal of Business Research, 61(10), 1030-1040. doi.org/10.1016/j.jbusres.2007.09.019

Raijas, A., Lehtinen, A., \& Leskinen, J. (2010). Journal of Consumer Policy, 33(3), 209-223. doi: 10.1007/s10603-010-9131-8

Ribeiro, C. A., Vieira, K. M., Santos, J. H. A., Trindade, L. L., \& Mallmann, E. I. (2009, August). Finanças pessoais: análise dos gastos e da propensão ao endividamento em estudantes de administração. Anais do Seminários em Administração, São Paulo, SP, Brasil, 12.

Schneiderman, L. J. (2005). The perils of hope. Cambridge Quarterly of Healthcare Ethics, 14(2), 235-239.

Seligman, M. E. P. (1991). Learned optimism. New York: Knopf.

Smith, N. H. (2005). Rorty on religion and hope. Inquiry, 48(1), 76-98. doi: $10.1080 / 00201740510015365$

Snyder, C. R. (2000). Hypothesis: there is hope. In C. R. Snyder (Eds.), Handbook of hope: theory, measures, and applications (pp. 3-18). San Diego: Academic Press. 
Stasson, M., \& Fishbein, M. (1990). The relation between perceived risk and preventive action: a within-subject analysis of perceiving driving risk and intention to wear seatbelts. Journal of Applied Psychology, 20(19), 1541-1557. doi: 10.1111/j.1559-1816.1990.tb01492.x

Stone, R. N., \& Gronhaug, K. (1993). Perceived risk: Further considerations for the marketing discipline. European Journal of Marketing, 27(3), 39-50. doi: 10.1108/03090569310026637

Stone, R. N., \& Winter, F. W. (1987). Risk: is it still uncertainty times consequences. Proceedings of the American Marketing Association Winter Educators Conference, Chicago, IL, USA.

Taylor, J. W. (1974). The role of risk in consumer behavior. Journal of Marketing, 28(2), 226-231.

Temoshok, L., Sweet, D. M., \& Zich, J. (1987). A three city comparison of the public's knowledge and attitudes about AIDS. Psychology and Health, 1(1), 43-60. doi: $10.1080 / 08870448708400314$

Vanzellotti, C. A. (2007). Esperança pra dar e vender: a esperança no consumo de cosméticos antisinais (Dissertação de mestrado). Universidade Federal do Rio Grande do Sul, Porto Alegre, RS, Brasil.

Vieira, V. A. (2008, Setembro). Quais fatores compõem a esperança no consumo de bens e com quais variáveis de marketing ela se relaciona? Encontro Nacional da Associação Nacional dos Programas de Pós-Graduação em Administração, Rio de Janeiro, 32.

Vitt, L. A. (2004). Consumers financial decisions and the psychology of values. Journal of Financial Service Professionals, 58(6), 68-77.

Wang, T. (2007). The influence of advertising claims on consumer's hope and product evaluations (Master article). National Cheng Kung University, Taiwan.

Weber, E. U., Blais, A. R., \& Betz, N. E. (2002). A domain-specific risk-attitude scale: measuring perceived risks and risk behaviors. Journal of Behavioral Decision Making, 15(4), 263-290. doi: $10.1002 / \mathrm{bdm} .414$

Weber, E. U., \& Milliman, R. (1997). Perceived risk attitudes: relating risk perception to risky choice. Management Science, 43(2), 122-144. doi: 10.1287/mnsc.43.2.123

Weinstein, N. D. (1984). Why it won't happen to me: perceptions of risk factors and susceptibility. Health Psychology, 3(5), 431-457. doi: 1988-14426-001

Zikmund, W. G., \& Scott, J. E. (1974). Variety analysis of perceived risk self-confidence and information sources. Advances in Consumer Research, 1, 406-416.

Yates, J. F, \& Stone, E. R. (1992). The risk construct. In J. F. Yates (Ed.). Risk-taking Behavior (pp. 325). New York: John Wiley. 